\title{
Role of nutrient and oxygen demand in the aquatic system
}

\author{
SufiaIrfan \\ Biology Department, College of Science,Faculty of Science, University of Tabuk, Tabuk-71491, Saudi Arabia
}

\begin{abstract}
The Study was conducted to determine the effect of nutrient and oxygen role in the in two different aquatic ecosystems.Oxygen demand available in the water column affects the macrophytes growth and water quality of the aquifers. The study was carried out in two different aquatic ecosystems one situated in the urban area and another in the agricultural surrounding with rural deem.
\end{abstract}

Keywords: Biochemical oxygen demand,Dissolved oxygen, Nitrogen, Phosphorus, Wetland

\section{Introduction}

Wetlands have important role in water quality control (Nixon \& Lee, 1986). They perform as sinks for nutrients like nitrogen and phosphorus (Howard -Williams, 1985). Aquatic ecosystemsare complex and fragile entity on the earth's surface, can readily accumulate pollutants at their bottom and are essential and integral part of human life. Their scenic beauty, religious and cultural values make them more valuable. Fresh water systems influence social activities, provide habitat for fishes, a niche for migratory birds in favorable season and the most important limitless drinking water for diverse species of mammals. Wetlands have a remarkable ability to filter and control nitrogen $(\mathrm{N})$ and phosphorus $(\mathrm{P})$ movement into different water; few studies, however, have examined the roles that individual plant species serve in sequestering $\mathrm{N}$ and $\mathrm{P}$ pollutants. In surface water phosphorus occurs as a particulate $\mathrm{P}$ and dissolved phosphorus consisting mainly of orthophosphate, available to plants. Particulate P represents the long-term source of plants (Reddy et al., 1999). Sources of phosphorus in aquatic ecosystems include influx from municipal and residential domestic sewerage system, cropland and urban water runoff, and natural decay of vegetation. Direct discharge of pollutants from point source and nonpoint sources into an aquatic body creates an oxygen demand that may bring DO below acceptable concentrations. High nutrient levels in water bodies can occasionally cause sufficient eutrophication to generate BOD loads from decaying algae. This may be observed in the water system with slow current and algae population.This paper has evaluated the role of oxygen demand and nutrient (Nitrogen and Phosphorus) in the two freshwater aquaticecosystemsstatus situated in the rural and urban region in eastern province of Indian subcontinent.

\section{Material And Methods}

Dissolved oxygen and BOD was determined by Winkler's iodometric method (APHA, 2008).

Where,

$$
\text { DO } \operatorname{mg~} 1^{-1} 1=\frac{\mathrm{ml} * \mathrm{~N} \text { of thiosulphate } * 8 * 1000}{\mathrm{~V}_{1}-\mathrm{V}}
$$

$$
\begin{aligned}
& \mathrm{V}_{1}=\text { volume of sample water }=300 \mathrm{ml} \\
& \mathrm{V}=\text { volume of } \mathrm{MnSO}_{4} \text { and } \mathrm{KI}
\end{aligned}
$$

The five-day oxygen demand (B.O.D.) ${ }_{5}$ was used to measure the oxygen demand required in biological activities. It was measured in water samples of vertical profile at monthly intervals. Nitrate content in the water sample was determined by using phenol di sulphonic acid method (PDSA). It depends upon the nitration of sixth position of 2, 4 di sulphonic acid in the presence of fuming sulphuric acid.

$\mathrm{C}_{6} \mathrm{H}_{3} \mathrm{OH}\left(\mathrm{HSO}_{3}\right)_{2}+\mathrm{HNO} 3 \rightarrow \mathrm{C}_{6} \mathrm{H}_{2} \mathrm{OH}+\left(\mathrm{HSO}_{3}\right)_{2} \mathrm{NO}_{2}+\mathrm{H}_{2} \mathrm{O}$

Phosphorus in the sample water was measured by stannous chloride method. Ammonium molybdate solution and stannous chloride solution in glycerol were added to the water sample. The development of blue color indicated the presence of phosphate phosphorus.

\section{Result}

In rural wetland two peaks of dissolved oxygen values were recorded. It was $9.2 \pm 1.09 \mathrm{mg}^{-1}$ values in the month of August and $7.8 \pm 0.52 \mathrm{mg} 1$ in the month of January (Fig: 1). 


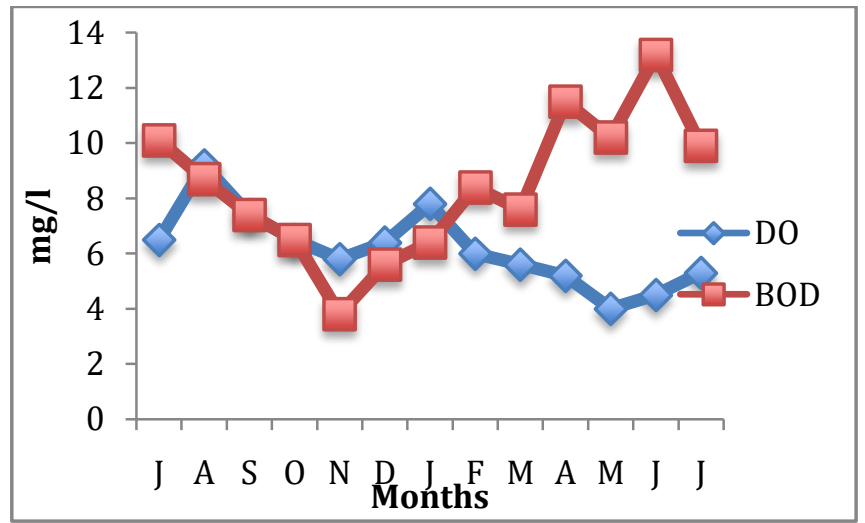

Fig1- DO and BOD value in the water column of rural aquatic ecosystem

The value of BOD in rural wetland was recorded high $\left(13.2 \pm 0.61 \mathrm{mg} \mathrm{l}^{-1}\right)$ in the month of June and was minimum $\left(3.8 \pm 0.58 \mathrm{mg} \mathrm{l}^{-1}\right)$ in the month of November (Fig: 1).In the urban aquatic systemhighest dissolved oxygen was recorded in the month of December $(14.5 \pm 0.75)$. Urban pond showed the high BOD value $\left(35.8 \pm 0.70 \mathrm{mg} \mathrm{l}^{-1}\right)$ of in the month of July and low $\left(5.4 \pm 0.40 \mathrm{mg} \mathrm{l}^{-1}\right)$ in the month of December (Fig: 2$)$ respectively.

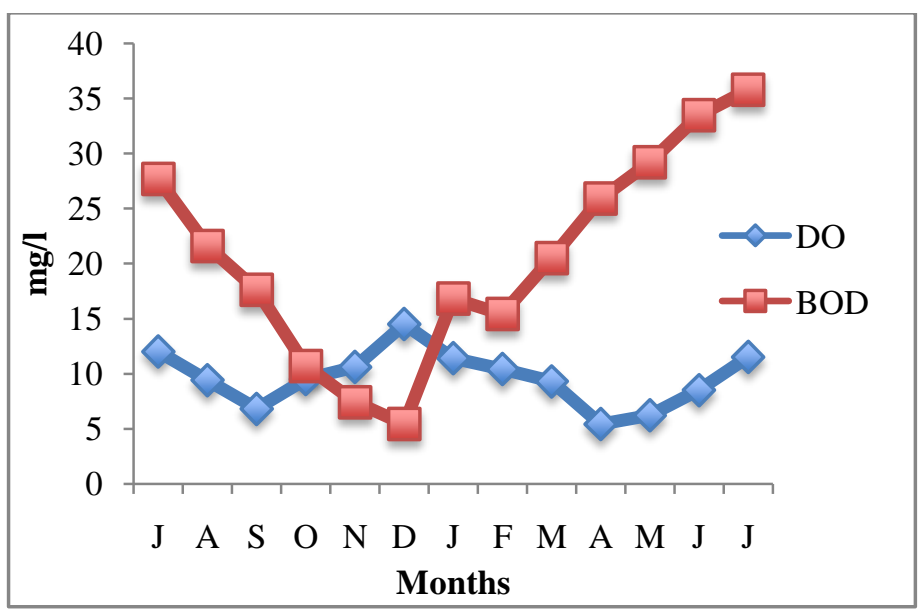

Fig2- DO and BOD value in the water column of urban aquatic ecosystem

In water column of rural aquatic system of $\mathrm{NO}_{3}-\mathrm{N}$ was high in the rainy season. The highest value $\left(0.99 \pm 0.08 \mathrm{mgl}^{-1}\right)$ was measured in the month of July (Fig: 3). The maximum $\left(1.42 \pm 0.18 \mathrm{mgl}^{-1}\right)$ value for total nitrogen was recorded in rural wetland for the month of July and $\left(1.48 \pm 0.10 \mathrm{mgl}^{-1}\right)$ in the month of October for urban aquatic body (Fig: 4).In urban aquatic ecosystem minimum value of $\mathrm{NO}_{3}-\mathrm{N}$ in water column was measured $\left(0.40 \pm 0.01 \mathrm{mgl}^{-1}\right)$ in the month of June (Fig: 4). The values in late summer and early rainy months were higher than late rainy and winter months.

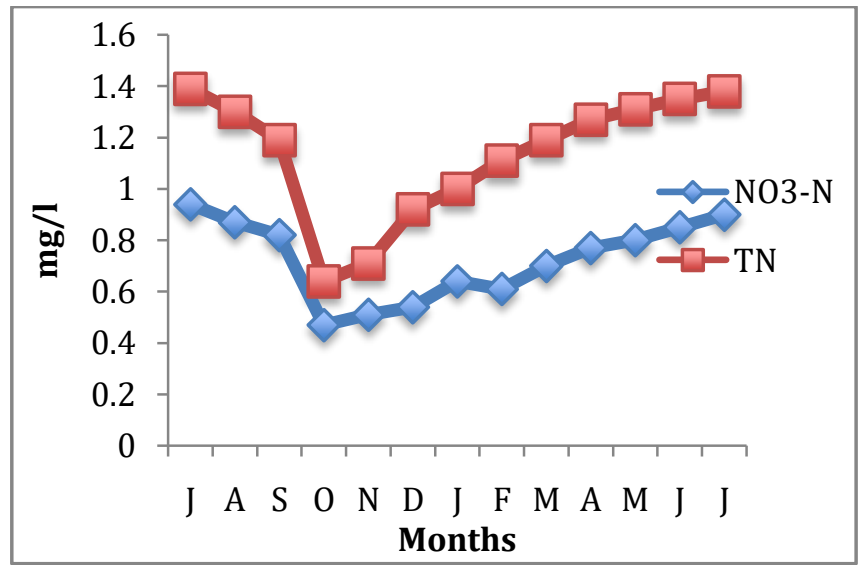

Fig 3- $\mathrm{NO}_{3}-\mathrm{N}$ and $\mathrm{TN}$ value in the water column of rural aquatic ecosystem. 


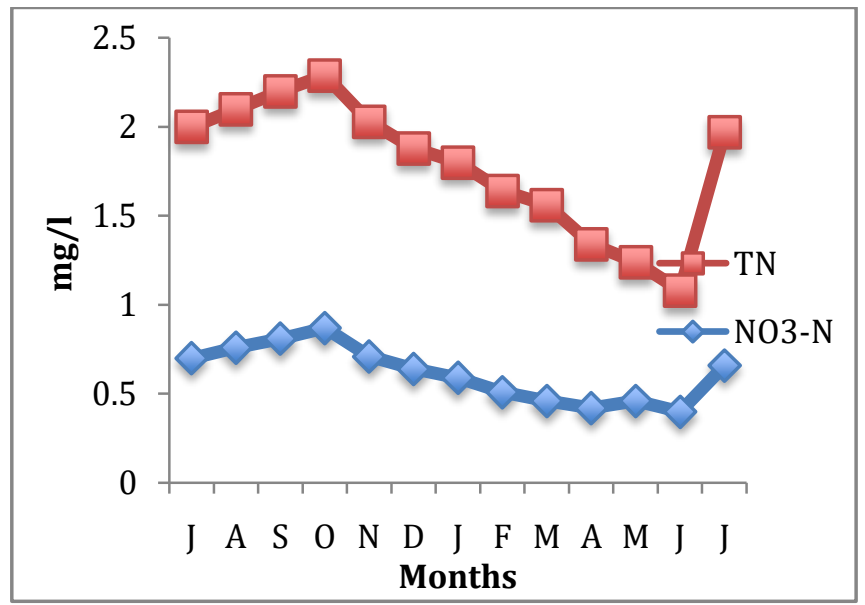

Fig 4- $\mathrm{NO}_{3}-\mathrm{N}$ and $\mathrm{TN}$ value in the water column of urban aquatic ecosystem.

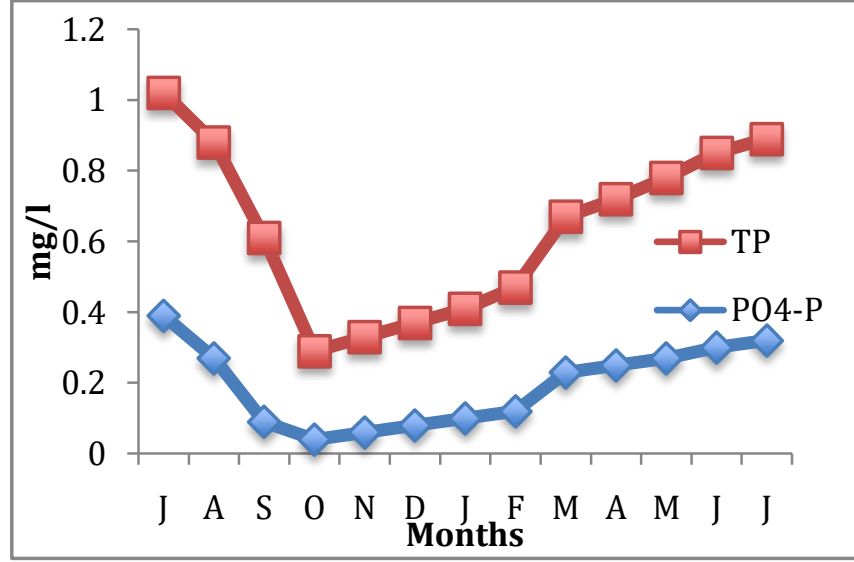

Fig 5- $\mathrm{PO}_{4}-\mathrm{P}$ and $\mathrm{TP}$ value in the water column of rural aquatic ecosystem.

Agricultural aquatic system located in the agricultural area had maximum value for total phosphorus in the month of July (Fig: 5). The higher values were recorded in the rainy season.

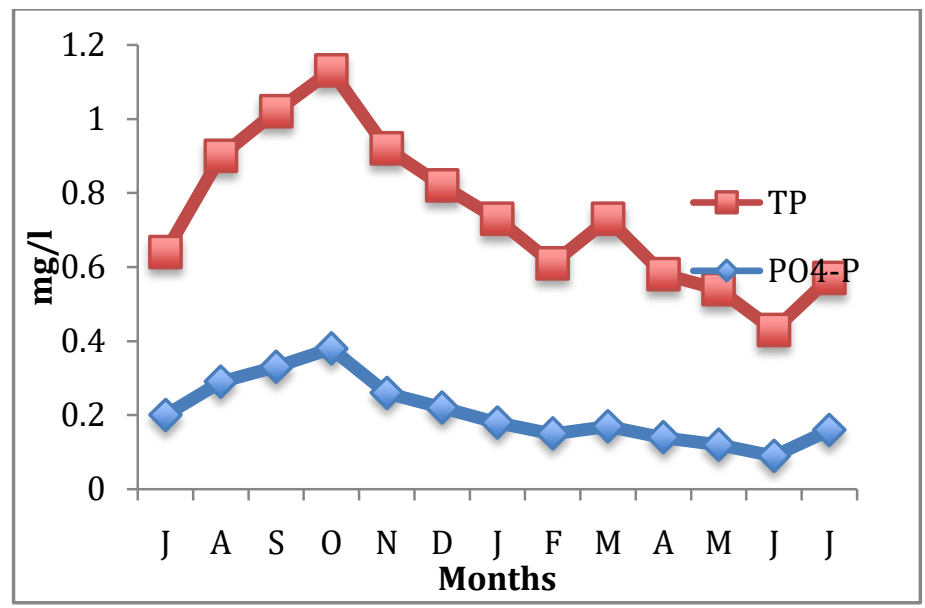

Fig 6- $\mathrm{PO}_{4}-\mathrm{P}$ and $\mathrm{TP}$ value in the water column of urban aquatic ecosystem.

In the urban area aquatic system maximum value $\left(0.79 \pm 0.10 \mathrm{mgl}^{-1}\right)$ was measured in the month of October and minimum value was recorded $\left(0.32 \pm 0.01 \mathrm{mgl}^{-1}\right)$ in the month of June (Fig: 6). Rainy months exhibit higher values whereas lower values were recorded in summer months. 


\section{Discussion}

Dissolved oxygen refers the volume of oxygen dissolved in the water and is more reactive and variable in the short term than most chemical constituents in water. Dissolved oxygen determines the quality and quantity of aquatic environment (Bharti and Katyal, 2011). DO is the single most important component of surface water for self-purification processes and the maintenance of aquatic biota. The prime source of oxygen in water is photosynthesis by aquatic macrophytes and mixing of atmospheric oxygen with surface water. After absorption oxygen either incorporates in to water body through existing internal currents or lost from the system. In rural water ecosystem value of DO shows maximum value for late rainy season or at the beginning of winter season and minimum value was measured in June. This could be partially attributed to the high water temperatures during summer. In urban aquatic body, DO was high in December month and lowin the month of April. In summer season depletion in oxygen occurs due to higher atmospheric temperature. Microbial activities use oxygen as source of energy to act upon complex organic molecules.Dissolved oxygen between the months varied significantly at $\mathrm{p}<0.01$ level on both rural and urban aquatic ecosystems. In hanuman tal lake, Jabalpur the dissolved oxygen varied between 3.0- $8.2 \mathrm{mg} \mathrm{l}^{-1}$ (Jain \&Dhamija, 2000). Rise in temperature alters the capacity of water to dissolve oxygen. In tropical region the winter season shows plenty of dissolve oxygen. Loss of oxygen also occurs due to photochemical oxidation by ultraviolet light (Gjessing\&Gjerdahl, 1970) at and near the lake surface. Miles and Brezonik, (1981) reported dystrophic waters show lower oxygen resulting due to abiotic, photochemical reaction with humus materials. Water temperature is important because it not only establishes the maximum oxygen-holding capacity of water, but also has direct influence on rates of biochemical reactions and transformation processes occurring within the water column and in the sediment bed. Warmer temperatures decrease oxygen solubility in water while at the same time increasing metabolic rates that affect BOD decay, sediment oxygen demand, nitrification, photosynthesis, and respiration. Low dissolved oxygen (DO) primarily results from excessive growth of algae due to phosphorus entry in the aquatic systems. Nitrogen is another nutrient that can contribute to algae growth. As the algae die and decompose, the process consumes dissolved oxygen. This can result in insufficient amounts of dissolved oxygen available for fish and other aquatic life. Die-off and decomposition of submerged plants also contributes to low dissolve oxygen.

Biochemical oxygen demand is the amount of oxygen required for the disintegration of organic matter present in the water through microbial activity. BOD values in turn indicate the amount of pollutants in aquatic system responsible for the deterioration of water quality. The B.O.D of water in rural aquatic system Presence of excess amounts of nutrients in water encourage microbial break down of wastes. In urbanaquatic body higher BOD value was determined in rainy season, in which precipitation results in maximum BOD of the water due to dispersion of organic solids to suspended condition. Minimum values of BOD in rural and urban water ecosystem was measured in the month of November and December respectively that might be due to low water temperature which helps in the slow rate of bacterial decomposition of autochthonous materials. At one-meter depth BOD decreases due to slow rate of decomposition at low temperature at both the sites. Urban aquatic system has higher rate of BOD due to inflow of sewage from nearby locality. This adversely affected the aquatic habitat. Vertical distribution in water column varied with season. In the rainy months value showed a gradual decline with depth. But in hot weather the value increased with depth due to less availability of oxygen. Biochemical oxygen demand fluctuation between the months varied significantly at $p<0.01$ levels on both rural and urban aquatic ecosystems.

The quantities of nitrogen, phosphorus and other biologically important nutrients are the primary indicator of water's trophic state index (TSI). Nutrients such as nitrogen and phosphorus tend to be limiting resources in standing water bodies; so increased concentrations tend to result in increased plant growth, as a result an increase in subsequent trophic status. Consequently, a body of water's trophic index may sometimes be used to make a rough estimate of its biological condition (EPA, 2007). The concentration of biologically available nitrogen and phosphorus are well known to play a key role in determining the ecological status of aquatic systems (Jarvie et al. 1998). Agricultural and urban activities are considered as being major sources of $P$ and $\mathrm{N}$ to aquatic ecosystems. Nitrate nitrogen $\left(\mathrm{NO}_{3}-\mathrm{N}\right)$ is inextricably involved with biological actions of the water bodies. Nitrogen is an important limiting nutrient in tropical lakes. The sources, which contribute nitrate nitrogen to the fresh water system, are precipitation and cyano-bacterial fixation. In some lakes with watershed precipitation is the most important source of nitrogen (Wetzel, 1975). Nitrate nitrogen acts as electron acceptor, which increases redox potential of sediments and hence involve in phosphorous binding capacity of sediments. When overall production in a lake is high, sources of nitrate nitrogen act as the inhibiting factor (Vollenweider, 1968). The surface water values for nitrate nitrogen in both the aquatic bodies were higher in the rainy season. Maximum concentration in nitrates during rainy season appears to arrive as a consequence of precipitation and runoff flow from adjacent areas. Minimum values in summer and winter season are the result of assimilation by the primary producers and denitrification processing. Nitrate- $\mathrm{N}$ decreased as depth increases due to reduction and less biological activities. As water level increases to its maximum in rainy season, surface values of nitrate also increase resulted from the addition of runoff. In Nitrogen recycling within the river is the result of 
demineralization from dead plant cells. According to a report nutrient demineralization rates increases with increasing temperature and therefore rapid in summer. This results in increase in the summer supply of nitrogen, which in turn boost the maximum algal biomass. Variation in concentration of nitrate nitrogen and phosphate phosphorus between the months was highly significant $(\mathrm{p}<0.01)$ level in both the study sites.

Phosphorus role in a fresh water system is limiting (Hutchinson, 1957). Rainfall, runoff waters and decomposed waste materials are the sources of $\mathrm{PO}_{4}-\mathrm{P}$ to the fresh water systems. Phosphorus forms a base for nucleic acids, and biochemical energy essential for life processes to occur. Organic phosphorus is present within the biological residue of the plants and animals. Rural wetland had maximum value of phosphorus in July and lower values in late rainy season for surface water. In urban aquatic ecosystem maximum surface water $\mathrm{PO}_{4}-\mathrm{P}$ was in the month of October. Mean value of phosphorus was higher in wet months and early winter months, which indicates arrival of fertilizer from arable lands to the water body. In dry season less mean value of phosphorus was determined. Any deficiency of phosphorus in a lake limits the productivity of lake. The anthropogenic sources of phosphorus in water ecosystem include runoff mined for phosphates, agricultural land and urban areas. Indian fresh water systems receive considerable amount of phosphorus through washing detergents in both the rural and urban areas. Urban aquatic system receives much of phosphorus coming from washing detergents through the daily routine activity of the people residing in adjacent areas. Phosphorus exchange between the lake bottom and the overlying water is a part of the phosphorus cycle. Decayed vegetation also contributes some phosphate. Increase in total phosphorus occurs as a result of release of phosphate from lake sediment. The high nutrient concentration in the winter season was the result of high external nutrient loading. Phosphate consumption increases during productive periods resulted in the lower value of the same.Both $\mathrm{N}$ and $\mathrm{P}$ are important as limiting factors.

\subsection{Effect of dissolved oxygen on aquatic life}

Plants, in general, only produce oxygen when light is available for photosynthesis. Rooted aquatic plants are more abundant in lakes and impounded rivers than in rivers with significant current or in streams. Large daily fluctuations in dissolved oxygen are characteristic of bodies of water with extensive plant growth. DO levels rise from morning through the afternoon as a result of photosynthesis, reaching a peak in late afternoon. Photosynthesis stops at night, but plants and animals continue to respire and consume oxygen and thereby DO level falls. Dissolved oxygen levels may dip below $4 \mathrm{mg} / \mathrm{l}$ in such waters - the minimum amount needed to sustain warm water fishes.

The exact levels of DO vary depending on the temperature of the water, the amount of photosynthesis occurring and the quantity of dissolved oxygen used for respiration by aquatic life. Reduced DO levels in stream water may be because the water is too warm. The increased molecular activity of the warm water pushes the oxygen molecules out of the spaces between the moving water molecules.Decreased DO levels may also be indicative of too many bacteria and an excess amount of biological oxygen demand - BOD (untreated sewage, partially treated sewage, organic discharges, anoxic discharges) that use up DO.

Another reason for decreased DO may be fertilizer runoff from farm fields and lawns. The same fertilizer, which was meant to make land plants grow better, now makes the aquatic plants do the same. If the weather becomes cloudy for several days, respiring plants will use much of the DO while failing to photosynthesize. When the increased numbers of aquatic plants eventually die, they support increasing amounts of bacteria, which use large amounts of DO.

Depletion in DO can cause major shifts in the variety of aquatic biota found in water bodies. Certain pollutants interfere with oxygen uptake and metabolism so that some species of aquatic animals may need higher DO levels when these pollutants are present.

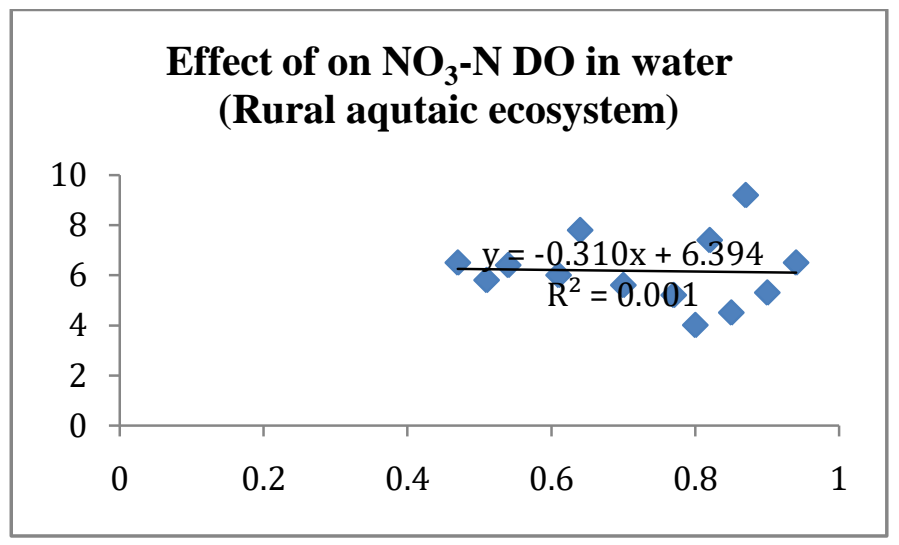


Regression equation for $\mathrm{DO}$ and $\mathrm{NO}_{3}-\mathrm{N}$

$\mathrm{DO}=6.394-0.311\left(\mathrm{NO}_{3} \mathrm{~N}\right) \quad \mathrm{y}=-0.3106 \mathrm{x}+6.3943$ (constant)

$\mathrm{R}^{2}=0.0012$

With $\mathrm{p}=0.08$ (significant)

$\mathrm{DO}$ is the dependent variable, its relationship is seen with $\mathrm{NO}_{3}-\mathrm{N}$ in the equation given above. Whereas $\mathrm{NO}_{3}-\mathrm{N}$ changes, there is a fall in DO.

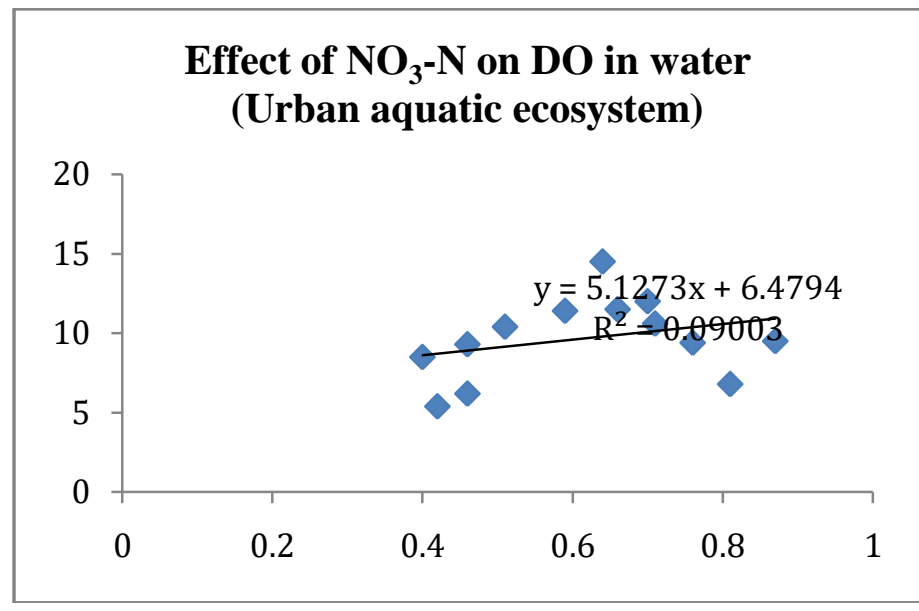

Regression equation for $\mathrm{DO}$ and $\mathrm{NO}_{3}-\mathrm{N}$

$\mathrm{DO}=6.4794-5.1273\left(\mathrm{NO}_{3} \mathrm{~N}\right) \quad \mathrm{y}=-5.1273 \mathrm{x}+6.4794$ (constant)

$\mathrm{R}^{2}=0.0900$

With $\mathrm{p}=0.08$ (significant)

\section{Conclusion}

Dissolved oxygen is an important parameter in evaluation of water quality because of its direct influence on the flora and fauna within a body of water. Excess nitrogen and phosphorus runoff can aggravate macrophytes and algal growth that decompose; therebyreleasing organic matter, which declines dissolved oxygen levels, especially near the bottom of the aquatic ecosystem. Dissolved oxygen level whether too high or too low can harm aquatic biota and affect water quality. In both the rural and urban freshwater systems, effect of DO and nutrient availability in the water found to affect the productivity and function of the aquatic system.

\section{References}

[1]. Nixon. S.W. and V. Lee. 1986. Wetlands and water quality: a regional review of recentresearch in the United States on the role of freshwater and saltwater wetlands as sources, sinks, and transformers of nitrogen, phosphorus, and various heavy metals. Army Corp of Engineers. Waterways Experiment Station. Vicksburg. Mississippi. Technical Report Y-86-2. 229pp.

[2]. Howard-Williams C. 1985. Cycling and retention of nitrogen and phosphorus in wetlands: a theoretical and applied perspective. Freshwater Biology 15: 391-431.

[3]. Reddy K R, Kadlec R H, Flaig E, Gale P M. 1999. Phosphorus retention in streams and wetlands: A review. Critical Reviews in Environmental Science \& Technology 29: 83-146.

[4]. American Public Health Association (APHA). 1995. Standard methods for the examination of water and wastewater. 19 $9^{\text {th }}$ ed, Washington D.C.

[5]. Bharti, N; Katyal, D. 2011. Water quality indices used for surface water vulnerability assessment. International Journal of Environmental Sciences 2 (1) 154-173.

[6]. Jain Y, Dhamija S K. 2000. Studies on apolluted lentic water body of Jabalpur with special reference to its physicochemical and biological parameters. Journal Environment Pollution 7 (2): 83-87.

[7]. Gjessing E T, Gjerdahl T. 1970. Influence of ultraviolet radiation on aquatic humus. Vatten 26: 144-145.

[8]. Miles C J, Brezonik P L. 1981. Oxygen consumption in humiccoloured waters by a photochemical ferrous ferric catalytic cycle. Environmental Science and Technology 15: 1089-1095.

[9]. United States Environmental Protection Agency (2007) Carlson's Trophic State index. AquaticBiodiversity http://www.epa.gov/bioindicators/aquatic/carlson.html accessed 17 February 2008.

[10]. Jarvie H P, Whitton B A, Neal C. 1998.

[11]. Nitrogen and phosphorus in east coast British rivers: Speciation, sources and biological significance Science of Total Environment 210-211: 79 .

[12]. Wetzel R G. 1975b. Limnology. W B Saunders Co., Philadelphia.

[13]. Vollenweider R A. 1968. Scientific fundamentals of the eutrophication of lakes and flowing waters, with particular reference to nitrogen and phosphorus as factors of eutrophication. OECD, Paris. Technical Report DA5/5C1/ 68-27.

[14]. Hutchinson G E. 1957. A treatise on limnology. Vol. III, Limnological Botany, John Wiley and Sons. 660. 